\title{
Alexander Hepburne Macklin: physician, polar explorer, and pioneer
}

\author{
I D Levack, S W McGowan
}

Western General Hospital, Edinburgh I D Levack, consultant anaesthetist

Dundee Royal Infirmary, Dundee

S W McGowan, consultant anaesthetist (retired)

Correspondence to: Dr Levack.

BMF 1993;307:1597-9
Earlier this year Sir Ranulph Fiennes and Dr Michael Stroud completed the first unsupported crossing of the Antarctic continent-nearly 80 years after Shackleton's attempted Imperial Trans-Antarctic Expedition. Shackleton's expedition failed in its objective yet became one of the most remarkable triumphs of group survival. ${ }^{12}$ Alec Macklin was its medical officer.

\section{Polar exploits}

Antarctica is a convexity of land mainly covered with snow and ice to make the world's sixth continent. Ernest Shackleton had been a member of Scott's expedition in 1901-4, and in 1907-9 he commanded an expedition that came within 100 miles of the South Pole ${ }^{3}$ but turned back because of scurvy. He decided he would cross the continent from Weddell Sea to Ross Sea by way of the Pole, describing it as "the last great journey on earth." In 1914 his expedition sailed and aboard Endurance eventually entered the Weddell Sea, where the ship became beset in pack ice (fig 1) before sighting an appropriate landing point onto the Antarctic iceshelf. It was gradually crushed by the weight of the ice (fig 2) and sank, leaving the crew stranded with their meagre stores and three lifeboats. For five and a half months the 28 men camped on ice floes in the middle of the Weddell Sea, all the while drifting some 1600 miles northwards. The floes finally began to break
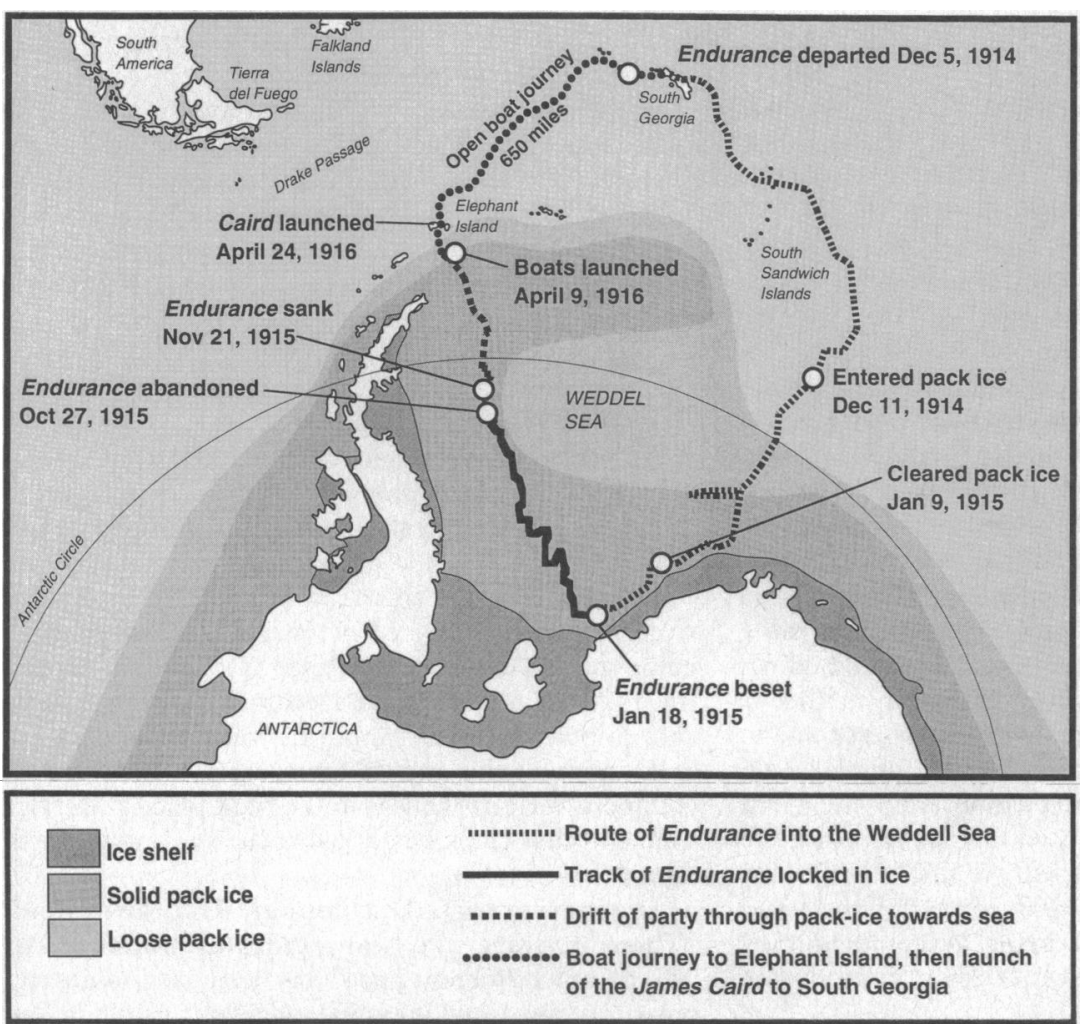

FIG 1-Map of Shackleton's expedition up when they were 60 miles southeast of the small, bleak, inhospitable Elephant Island.

It took the men six days in their open boats to reach Elephant Island, during which they were continuously wet through, seasick, frostbitten, and increasingly dehydrated because of lack of fresh water. They made a landfall with delirious relief-they were on solid rock again for the first time for 16 months.

The ordeal was not yet over. With no telecommunication they would have to risk the lives of a few for the preservation of the group. South Georgia was 800 miles distant. Their three boats could not have kept together, and the smaller two would have foundered. They therefore concentrated their meagre resources on the largest boat, the fames Caird. Navigational accuracy would be crucial; if they sailed past South Georgia to the north or south they would be swept out into the southern Atlantic with no chance of survival.

Shackleton and five others set sail in the fames Caird while Macklin remained with the main party on Elephant Island. The journey took 16 days, with only a few opportunities to fix a position by sextant and chronometer. They reached South Georgia at the opposite side to the whaling stations. Shackleton decided to cross the island on foot with the two fittest of his companions. Inadequately clothed and equipped, they set out across mountains which had not been traversed before, and 36 hours later they walked into the whaling station at Stromness. Three months later Shackleton finally reached the remainder of his party (fig 3), including Macklin, who had been waiting; starving and cold, on Elephant Island. All 28 men returned safely.

Macklin had reason to be especially disappointed by the outcome of the expedition. He had been chosen by Shackleton as one of the six man team to undertake the crossing of Antarctica. His specialist knowledge of how to treat snowblindness and frostbite and prevent scurvy were high on the list of priorities. ${ }^{46}$ Also, he had the veterinary care of the dog teams, which were destroyed and eaten after the loss of the Endurance. On Elephant Island, in a makeshift hut heated by burning penguin skins and using every available blubber lamp, he gave the chloroform while Mcllroy, the other medical officer in the group, amputated the frostbitten toes of one of their comrades. That the patient survived is a testimony to their skill and perhaps to good fortune. The privation and near starvation of the group, with the ever present anxiety of possible doom, ${ }^{7}$ were as remarkable as the efforts of their leader and his companions in their daring return to South Georgia and their subsequent efforts to retrieve the main party.

\section{Life of an Antarctic medical officer}

Macklin was born in Melrose but spent his boyhood in the Scilly Isles, where his father had a medical practice that involved journeying around the islands in small boats. The young Macklin therefore grew up 


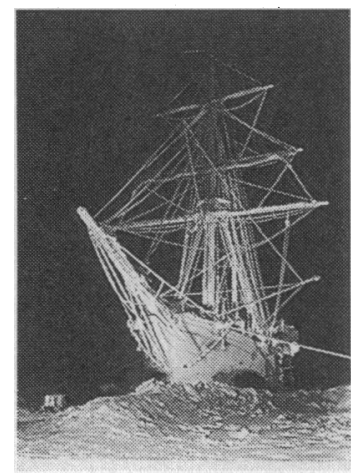

FIG 2-The "Endurance" covered with heavy rime on a brilliantly clear moonlit night in Fune 1915. Hurley, the expedition photographer used all his remaining flash powder to create this famous plate.

Reproduced with permission of Scott Polar Research Institute with the sea. Between leaving school and entering Manchester University he worked as a deckhand on a boat in the Mediterranean. As a medical student, his discovery of the two volumes of Furthest North by Nansen inspired his interest in polar exploration. ${ }^{8}$

When the Endurance expedition was announced, Macklin presented himself early one morning at the office in New Burlington Street, to meet what he called a "living avalanche" coming down the stairs: "Shackleton himself, obviously going out," he wrote in a diary account. Macklin was told to go upstairs and wait.

In the afternoon, Shackleton finally returned, still in a hurry.

The interview was brief:

"Why do you want to go?"

"I don't know, I just want to."

"You look fit enough; are you perfectly healthy ...?"

"Perfectly fit."

"What is wrong with your eyes?"

"Nothing." (Macklin was short sighted.)

At this I could have kicked myself for not removing my spectacles before going in to see him. I scarcely knew what to
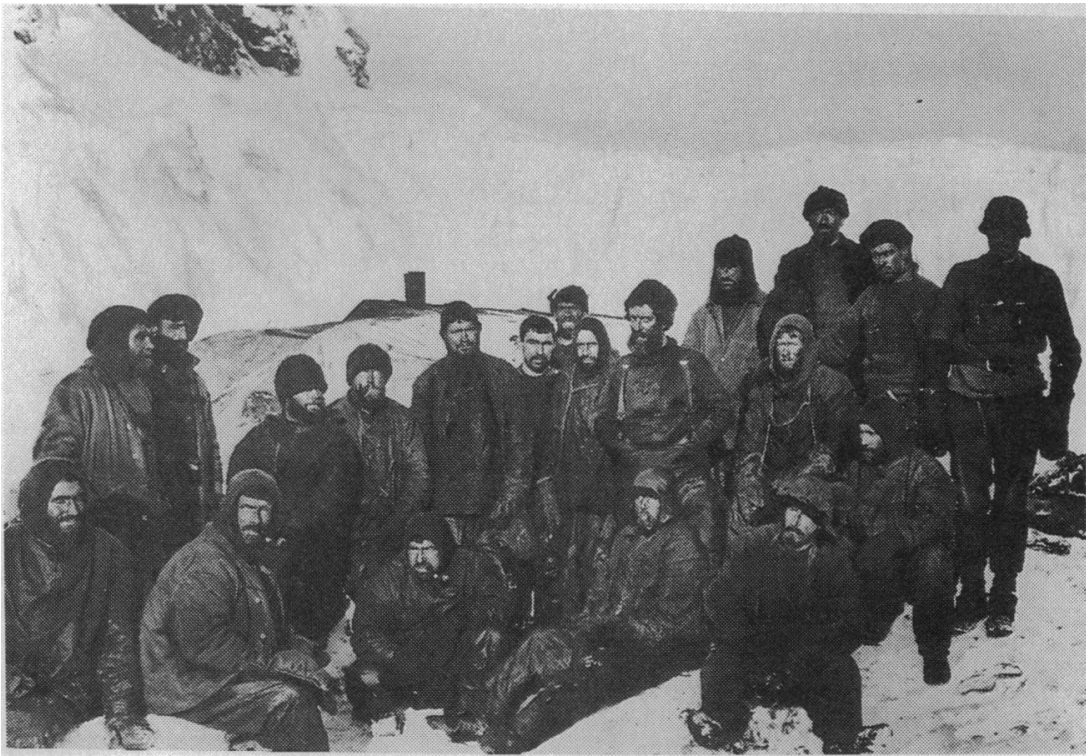

FIG 3-The marooned party on Elephant Island while Shackleton went for help. Macklin is standing on the extreme right. Their average age was 35 years. Reproduced with permission of Scott Polar Research Institute

say, but replied almost without thinking, "Many a wise face would look foolish without specs" [fig 4]. At this he laughed, then seemed to be thinking of something else for he remained silent for several minutes. "All right, I'll take you," he said, and with that pushed me out of his office.

It seems this was a fairly typical manner in which Shackleton selected his team, relying on his own intuition and his observations of body language.

Ten days after returning to Britain in 1916 Macklin was posted to a tank regiment in France as medical officer before joining the West Yorkshire Regiment. He volunteered for northern Russia as soon as the opportunity arose. Macklin's duties included treating extensive outbreaks of scurvy - on which he made a number of observations-smallpox, typhus, and typhoid. The most challenging task was to visit a colony of Laplanders who had been scourged by an influenza pandemic ${ }^{9}$ and who had seen neither a European nor a doctor before. His military task was to assess and test methods of transport of sick and wounded down a line of evacuation from the front during the North Russian Winter Campaign. After the war, his MD thesis was based on this work, ${ }^{10}$ and receiving the Polar Medal, OBE, Military Cross, and Order of St Stanislaw and being twice mentioned in dispatches indicate the level of his activity during 1914-9.

Shackleton's esteem for Macklin was apparent with the Quest Expedition in 1921. Macklin was one of the hard core from the Endurance expedition, some of whom had rejoined their trusted leader. It became increasingly obvious that Shackleton was unwell with angina, and he died aboard his ship in the bay at Grytviken, South Georgia. Macklin had the gruesome task of doing a postmortem examination on his friend and "boss," who was in his 48th year. He confirmed extensive coronary atheroma. ${ }^{11}$

\section{To Scotland}

In 1925 Macklin returned to his native country and whether by chance or design settled in general practice in Dundee-so closely connected with the Endurance expedition. He joined the staff of the Royal Infirmary and worked as a chloroformist for five years, during which he collated his anaesthetic records and in particular a series using nitrous oxide and oxygen in preference to the more popular techniques using ether or chloroform. ${ }^{12}{ }^{13}$ At that time it was considered a promotion in the hospital hierarchy to become a physician or surgeon, and he took charge of the electrocardiogram department.

His work was interrupted by the second world war. As a Territorial he was called up on the first day and not released until 1946. Initially he commanded a Field Ambulance in the 51st Highland Division, always leading it from the front on many marches and imparting in his troops a practical and doubtless unrivalled knowledge of combat survival.

In 1945 he was disappointed to find his department in Dundee "in chaos"; worse still, all his previously gathered records had been scattered. He decided to "retire" two years early.

In 1947 Macklin was appointed physician in charge of the student health service in the University of Aberdeen, which carried an honorary appointment as physician on the staff of Aberdeen Royal Infirmary and included the medical care of the nursing staff. He contributed much to the postwar development of student health services throughout Britain ${ }^{14}$ and was elected one of the first presidents of the British Student Health Association in 1952. In 1960, aged 70, he retired from his university practice, yet his energy and youthful spirit drove him to continue working full time during the next seven years.

At the time of his death Macklin was an orthopaedic house officer in a busy ward, a post he carried out with characteristic efficiency, though the anomaly was that some of the consultants were only half his years. One day he did not appear for work. Inquiry revealed he had gone home complaining of chest pain. Next day he died of a myocardial infarction.

\section{In retrospect}

"Always accept a chance or a challenge" was one of his favourite phrases, along with "We do not regret the things we have done half so much as the things we have not done."15

It was the nature of the man never to discuss the circumstances of any of his awards, which included being made a fellow of the Royal Geographical Society (in 1924) and Territorial Decoration-even with his wife (a nursing sister) whom he married on returning to Dundee at the end of the second world war. His comment was that he was in the right place at the right time and that chance had it that he was known by the right people.

An anonymous adaptation of Thoreau's words, "There are some who hear a different drummer, And who march a different pace" has been used to describe polar explorers, including the whalemen of old. ${ }^{16}$ They all marched a pace different from that set by the 
orthodox drummer of civilisation, yet Macklin, more so than Shackleton, displayed an ability to vary his step according to circumstances throughout a colourful life of diverse activities.

There can be few medical men who have had a mountain named after them. On South Georgia, Mount Macklin $\left(54^{\circ} 45^{\prime} \mathrm{S}, 36^{\circ} \mathrm{O} 3^{\prime} \mathrm{W}\right.$ with twin peaks, the higher at $1900 \mathrm{~m}$ ) in the Salvesen Range is an appropriate memorial to this most remarkable doctor.

We are indebted to Mrs Jean Macklin of Aberdeen for giving access to and further information on her late husband's diaries and papers. This paper is an abridged version of SWMcG's presidential address to the Scottish Society of Anaesthetists in 1991.

1 King P, ed. South: the story of Shackleton's last expedition 1914-17. London: Century, 1991.
2 Shackleton EH. South. London: Heinemann, 1919.

3 Shackleton EH. The heart of the Antarctic. London: Heinemann, 1909.

4 Macklin AH. Snowblindness. Lancet 1926;i:1226.

5 Macklin AH. The treatment of frostbite. Lancet 1925;:884-5.

6 Macklin AH, Hussey LDA. Scurvy: a system of prevention for a polar expedition, based on present day knowledge. Lancet 1921;ii:322-6.

7 Huntford R. Shackleton. London: Hodder and Stoughton, 1985:528-45.

8 Nansen F. Furthest north. London: Archibald, Constable, 1897.

9 Macklin AH. Influenza amongst the Lapps. BMY 1920;i:465-6.

10 Macklin AH. The evacuation of sick and wounded from mobile columns [dissertation]. Manchester: University of Manchester, 1920. 1923:35.

12 Macklin AH. Gas-oxygen as a routine anaesthetic; a summary of 200 cases. Lancet 1930;i:1231-5.

13 Macklin AH. The asphyxial element in gas-oxygen anaesthesia. Lancet 1931;ii:897-901. assessment. BMF 1956;ii:524-8.

15 Macklin AH. Three score and ten. Zodiac $-\mathcal{f}$ (Aberdeen University) 1960;7: 42-5.

16 Robertson RB. Of whales and men. London: Macmillan, 1956-57.
11 Macklin AH. In: Wild JRF. Shackleton's last voyage. London: Cassell and Coy,

14 Macklin AH. Some ideas in regard to the meaning of student health and its

\section{Walking across Antarctica}

\section{Fiona Godlee}

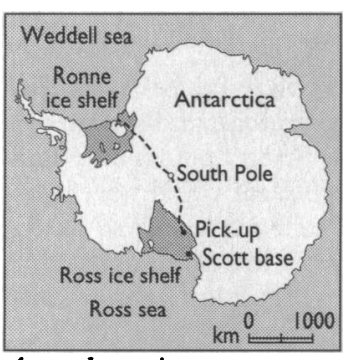

Across the continent
"An Englishman thinks he is moral only when he is uncomfortable," said George Bernard Shaw, and for a real expert at being uncomfortable you need look no further than Dr Mike Stroud. Earlier this year, after four attempts to walk to the North Pole, he and the explorer Sir Ranulph Fiennes completed the longest ever journey unsupported by men, animals, or machines and the first ever unsupported crossing of Antarctica. They were picked up-in Fiennes' words "more dead than alive"-after three months of extreme hardship, having hauled their sledges across more than $2000 \mathrm{~km}$ of frozen wastes and crevasses.

Poor short term memory was Mike Stroud's excuse when I asked him on his return why he put himself through such trials. He said that he forgets the bad bits. But bad bits there definitely were. On the third day of the Antarctic crossing Stroud nearly died when he fell into a crevasse. He was saved only by a crumbling ice bridge 20 feet below the surface. His sledge, which fell with him, was badly damaged. A faulty stove nearly set their tent and equipment on fire, including the vital radio with which they would eventully call to be picked up. After a month of walking in rigid ski boots-chosen instead of flexible boots so as to be able to pull the heavy sledge-an old ulcer on Fiennes's foot opened up. From then on until after the end of the expedition he was in constant and severe pain. Stroud lost his ski sticks, broke the bindings of his skis, and fractured his ankle. With wind chill temperatures as low as $-85^{\circ} \mathrm{C}$, both men suffered frostbite, diarrhoea, black depressions, and extreme hunger. Not, you might say, easy things to forget.

\section{The call}

Stroud, now 39 and working as a senior medical research officer for the Ministry of Defence, first set his sights on the Antarctic after seeing some photographs taken by a friend at medical school. "It really can be very beautiful," he said. After completing his house jobs in 1980 he joined the British Antarctic Survey, working as a doctor for three months, but found the experience limiting because safety regulations prevented him from straying far from the base. He returned, via South America, to England and senior house officer jobs. Three years later he was asked to join the Footsteps of Scott expedition and leapt at the

chance. This was a one way unsupported walk to the
South Pole led by Robert Swan and Roger Mear. In the end Stroud was not selected as one of the walkerssomething he still recalls with frustration-and he spent the year as the base camp doctor. Soon after his return, however, he received a call from Fiennes asking him to join him in a two man unsupported walk to the North Pole.

Stroud readily admits that he was some way down Fiennes's list of potential companions. His name was suggested when none of Fiennes's previous team members could go. The two men had never met, and since the plan was to manhaul sledges across the ice, carrying everything with them, Fiennes had envisaged a large brute of a man who would pull great loads without question. Stroud is not a large brute of a man-in fact in his book he describes himself as "very small." So how does he explain his ability? "In the end there are other things that are more important than size," he said, "and the most important of all is your mental attitude."

The idea to walk across the Antarctic continent had its roots in Sir Ernest Shackleton's heroic but failed attempt of 1914-16. Before he and his men reached even the starting point of the journey their ship, the Endurance, was crushed by pack ice in the Weddell Sea (p 1597). He led his men to safety by making the crossing to South Georgia-800 miles across the Southern Ocean in an open boat. Since then several groups have crossed the continent: Dr Vivian Fuchs and Sir Edmund Hillary in 1957, Fiennes and others in 1980-1, and two teams - one led by Will Steger, the other by Reinhold Messner and Arved Fuchs-in 1990-1. All, however, were supported, either by airdropped supplies or by using dogs or machines for transport. Fiennes and Stroud aimed to make the crossing without support of any kind. Fiennes initially refused even the assistance of wind power, but was persuaded that without sails they wouldn't make it. Even so, Fiennes admitted to Stroud that he believed they were attempting the impossible.

\section{A flair for hardship}

I first met Mike Stroud in 1988 when he was a medical registrar at St Thomas's Hospital in London. It was hard then-as it is now-to associate the news stories of heroic feats and failures with this slight, quietly spoken man, the more so because he never seemed to capitalise on his adventures. One day he

\section{London WC1H 9JR}

Fiona Godlee, assistant editor

BMF 1993;307:1599-601 